\title{
PEMBUATAN BRIKET AMPAS TEBU DAN SEKAM PADI MENGGUNAKAN METODE PIROLISIS SEBAGAI ENERGI ALTERNATIF
}

\author{
Agung Sugiharto, Zidni 'Ilma Firdaus* \\ Jurusan Teknik Kimia, Fakultas Teknik, Universitas Muhammadiyah Surakarta \\ Jl. A. Yani Tromol Pos 1 Pabelan Surakarta 57162 \\ "Email: zidni9ilma@gmail.com
}

\begin{abstract}
Abstrak
Kebutuhan sumber energi semakin meningkat seiring dengan meningkatnya konsumsi energi oleh masyarakat. Upaya dalam menemukan sumber energi terus dilakukan termasuk sumber energi baru terbarukan. Salah satu langkah yang banyak diteliti dan dikembangkan adalah biomassa. Briket merupakan bahan bakar alternatif dari pemanfaatan biomassa. Di Indonesia, limbah ampas tebu dan sekam padi mempunyai potensi yang cukup besar untuk dimanfaatkan sebagai energi terbarukan dalam bentuk briket. Manfaat pembuatan briket dapat mengurangi sampah yang menyebabkan pencemaran lingkungan. Penelitian inni bertujuan untuk mengetahui pengaruh metode pembakaran bahan baku terhadap kualitas briket yang dihasilkan sesuai dengan standar mutu briket. Parameter yang diuji yaitu kadar air, kadar abu, kadar zat terbang, kadar karbon, dan nilai kalor. Hasil yang didapat adalah briket sudah sesuai standar mutu untuk parameter kadar air dan nilai kalor. Sedangkan nilai kadar abu, kadar zat terbang, dan kadar karbon belum memenuhi stndar mutu. Briket terbaik yang menggunakan perbandingan massa ampas tebu dan sekam padi (3:2) gram dengan nilai kadar air 8,30\%, kadar abu 21,26\%, kadar zat terbang, 34,06\%, kadar karbon 44,69\%, dan nilai kalor sebesar 6869,846 kal/gram.
\end{abstract}

Kata Kunci: Briket, Ampas tebu, Sekam padi, Proksimat, dan nilai kalor.

\section{PENDAHULUAN}

Kebutuhan manusia pada peralatan ataupun bahan penghasil energi yang bebas polusi, mudah diaplikasikan, serta fleksibel dan juga dapat digunakan sebagai energi cadangan di luar ketergantungan kita terhadap energi yang selama ini disuplai oleh negara. Pencarian energi alternatif ini akan lebih meringankan beban negara karena dapat mengurangi jumlah kebutuhan energi masyarakat yang harus disediakan negara (Edwart, 2013).

Dengan menipisnya cadangan bahan bakar fosil, maka diperlukan pengembangan sumber energi alternatif khususnya yang dapat diperbaharui (renewable energy) seperti biomassa. Energi biomassa merupakan sumber energi yang perlu dikembangkan karena lebih ramah lingkungan, murah dan tidak membahayakan kehidupan manusia. Pengembangan energi ini berkaitan dengan pengurangan emisi $\mathrm{CO}_{2}$ dan mendorong pemanfaatan energi ini sebagai sumber energi masa depan dan berkelanjutan. Biomassa memiliki kandungan material organik yang kompleks yang tersusun atas selulosa dan lignin (Mangalla et al., 2019).

Biomassa adalah limbah benda padat yang dapat dimanfaatkan sebagai sumber bahan bakar. Energi biomassa dapat menjadi sumber energi alternative pengganti bahan bakar minyak bumi karena sifatnya yang dapat diperbarui dan relatif tidak mengandung unsur sulfur sehingga tidak menyebabkan polusi udara (Rumiyanti et al., 2018).

Briket adalah salah satu cara yang layak untuk mengubah resdu biomassa menjadi energi terbarukan dan bahwa kualitas briket bergantung pada jenis bahan baku biomassa yang digunakan dan kondisi operasi seperti kadar air, suhu dan penambahan substrat serta partikel ukuran (Oladeji, 2015). Keuntungan penggunaan briket dibandingkan dengan kayu bakar yaitu intensitas panas lebih besar, nyaman, bersih bila digunakan, dan membutuhkan ruang penyimpanan yang relative lebih kecil (Akenpuun et al., 2020).

Ampas tebu merupakan hasil sampingan dari proses pemerahan atau ektraksi cairan tebu, dari ektraksi tersebut menghasilkan ampas tebu yang berkisar antara $35-40 \%$ dari berat tebu yang digiling (Miskah et al., 2016).

Sekam padi adalah biomassa yang terdiri dari komposisi senyawa lignoselulosa, hemiselulosa dan lignin. Dalam proses karbonasi, dekomposisi selulosa, hemiselulosa dan lignin memiliki suhu dekomposisi termal yang berbeda (Suryaningsih and Nurhilal, 2018). 
Salah satu keuntungan dari sekam padi adalah ketersediannya yang berkelanjutan, karena tanaman padi diproduksi secara berkelanjutan. Sebagai produk biomassa, pembakaran sekam padi memiliki netralitas emisi karbon, dimana emisi karbon dihasilkan dalam proses pembakaran yang seimbang dengan karbon yang diserap kembali pada periode tanam berikutnya. Oleh karena itu, ini tidak hanya mengarah pada kelestarian lingkungan dan ekonomi tetapi juga stabilitas sosial-politik jangka panjang yang berkelanjutan (Suryaningsih et al., 2018).

Bahan perekat adalah suatu zat atau bahan yang memiliki kemampuan untuk mengikat dua benda melalui ikatan permukaan. Dengan adanya perekat akan membuat ikatan antara partikel semakin kuat, sehingga butir-butiran arang akan saling mengikat dan menyebabkan air terikat dalam pori-pori arang (Manisi et al., 2019). Penggunaan jenis bahan perekat dalam pembuatan briket akan mempengaruhi kualitas briket yang dihasilkan yaitu pada penyalaa dan pembakaran (Setiawan and Syahrizal, 2018).

Kriteria briket yang baik adalah briket yang telah memenuhi standar mutu sehingga dapat digunakan sesuai kebutuhan. Sifat fisika dan kimia merupakan sifat yang mempengaruhi kualitas bahan bakar briket (Manisi et al., 2019).

Tabel 1. Standar mutu dan kandungan briket di beberapa negara

\begin{tabular}{|c|c|c|c|c|}
\hline $\begin{array}{l}\text { Sifat } \\
\text { Briket } \\
\text { Arang }\end{array}$ & Indonesia & Jepang & Inggris & Amerika \\
\hline $\begin{array}{l}\text { Kandungan } \\
\text { air }(\%)\end{array}$ & 8 & $6-9$ & $3-6$ & 6,2 \\
\hline $\begin{array}{l}\text { Kandungan } \\
\text { zat } \\
\text { menguap } \\
(\%)\end{array}$ & 15 & $15-30$ & 16,4 & $19-24$ \\
\hline $\begin{array}{l}\text { Kadar abu } \\
(\%)\end{array}$ & 8 & $3-6$ & 5,9 & 8,3 \\
\hline $\begin{array}{l}\text { Kadar } \\
\text { karbon }(\%)\end{array}$ & 77 & $60-80$ & 75,3 & 60 \\
\hline $\begin{array}{l}\text { Kerapatan } \\
\left(\mathrm{g} / \mathrm{cm}^{3}\right)\end{array}$ & - & $1-1,2$ & 0,46 & 1 \\
\hline $\begin{array}{l}\text { Kekuatan } \\
\text { tekan } \\
\left(\mathrm{kg} / \mathrm{cm}^{3}\right)\end{array}$ & - & $60-65$ & 12,7 & 62 \\
\hline $\begin{array}{l}\text { Nilai kalor } \\
(\mathrm{kal} / \mathrm{g})\end{array}$ & 5000 & $\begin{array}{l}6000- \\
7000\end{array}$ & 7289 & 6230 \\
\hline
\end{tabular}

\section{METODOLOGI}

\subsection{Alat}

Alat yang digunakan dalam penelitian ini adalah alat pencetak briket, ayakan 60 mesh, Cawan porselin, Drum pembakaran, Hot Plate, Loyang Alumunium, Neraca analitik, Oven, Termometer.

\subsection{Bahan}

Bahan-bahan yang digunakan dalam penelitian adalah ampas tebu, sekam padi dan tepung tapioka.

\subsection{Tahapan pembuatan Briket \\ 2.3.1. Proses pengolahan bahan menjadi arang}

Ampas tebu dan sekam padi dibersihkan dari kotoran-kotoran yang masih menempel. Ampas tebu dan sekam padi yang sudah bersih kemudian dijemur selama \pm 3 hari sampai kering. Setalah bahan kering dilakukan proses pengarangan ampas tebu dan sekam padi pada suhu $500^{\circ} \mathrm{C}$ selama 1 jam dengan drum pembakaran dalam keadaan tertutup. Arang yang sudah jadi dikeluarkan dari drum kemudian dihaluskan menggunakan alu dan mortar serta diayak menggunakan mesh ukuran 60.

\subsubsection{Proses pembuatan perekat}

Perekat dibuat dengan mencampurkan tepung tapioka sebanyak 1 gram dengan air 17 $\mathrm{mL}$ didalam gelas beker berukuran $100 \mathrm{~mL}$. kemudian gelas beker diletakkan di atas hot plate suhu $165^{\circ} \mathrm{C}$ dan diaduk sampai tercampur rata sampai mengental.

\subsubsection{Proses pembriketan}

1. Arang ampas tebu dan sekam padi dicampur hingga homogen dengan perbandingan $(2: 3) ;(2.5: 2.5) ;(3: 2)$.

2. Kemudian campuran bahan baku dicampur dengan bahan perekat yang sudah dibuat.

3. Selanjutnya campuran bahan-bahan tersebut dimasukkan ke dalam cetakan briket berbentuk silinder yang berdiameter $3 \mathrm{~cm}$ dan tinggi $4 \mathrm{~cm}$ lalu dipadatkan.

4. Setelah itu, hasil cetakan briket di keluarkan perlahan-lahan dan ditimbang untuk memperoleh berat awal.

5. Siapkan oven yang digunakan untuk proses pengeringan briket

6. Suhu pengeringan diatur sebesar $110^{\circ} \mathrm{C}$ selama 30 menit. 
Briket yang sudah kering kemudian ditimbang untuk memperoleh berat akhir briket kemudian diuji kualitasnya.

\section{HASIL DAN PEMBAHASAN}

\subsection{Pengaruh Variasi Komposisi Bahan} Baku terhadap Kadar Air

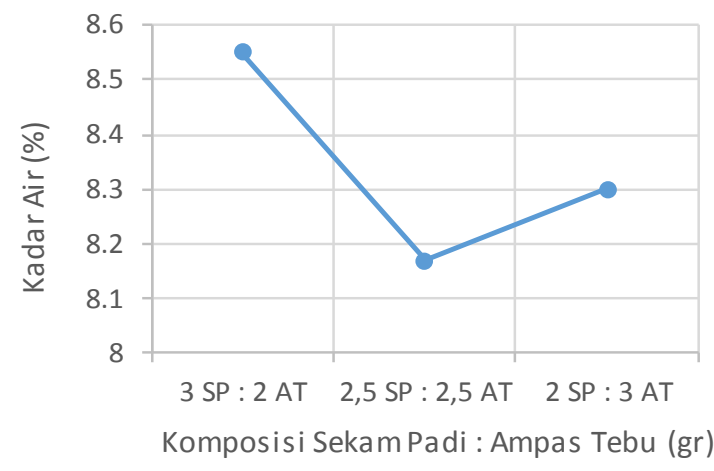

Gambar 1. Grafik pengaruh variasi komposisi bahan baku terhadap kadar air

Keseluruhan briket yang dihasilkan sudah sesuai dengan standar mutu dimana kadar air briket arang menurut SNI (SNI 01-6235-2000) yaitu sekitar $8 \%$. Kadar air briket yang dihasilkan pada briket dengan perbandingan komposisi bahan baku ampas tebu dan sekam padi 2,5:2,5 gram adalah kadar air yang terendah sebesar $8,17 \%$. Sedangkan kadar air tertinggi terdapat pada briket dengan perbandingan komposisi bahan baku ampas tebu dan sekam padi 2:3 gram yaitu $8.55 \%$. Kadar air yang tinggi dipengaruhi oleh penjemuran bahan baku kurang sempurna sehingga masih ada kandungan air dalam bahan baku dan jumlah pori-pori masih cukup banyak menyebabkan menurunnya efisiensi pembakaran briket.

Kadar air sangat mempengaruhi kualitas briket arang yang dihasilkan. Semakin rendah kadar air maka nilai kalor dan daya pembakarannya semakin tinggi begitupula sebaliknya. Semakin tinggi kadar air menyebabkan briket sulit dinyalakan pada saat dibakar dan menimbulkan banyak asap, selain itu juga dapat mengurangi temperature penyalaan dan daya pembakarannya. Penyimpanan briket sebaiknya diletakkan didalam desikator

\subsection{Pengaruh Variasi Komposisi Bahan Baku terhadap Kadar Abu}

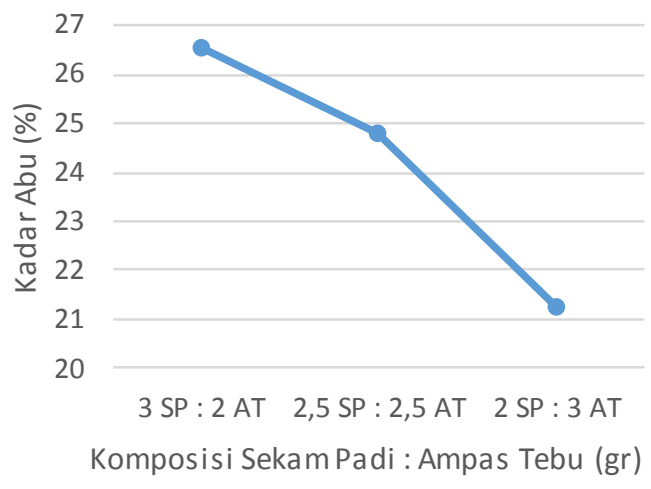

Gambar 2. Grafik pengaruh variasi komposisi bahan baku terhadap kadar abu

Dari grafik di atas dapat diketahui bahwa nilai kadar abu paling rendah yaitu briket dengan perbandingan komposisi sekam padi dan ampas tebu (2:3) gram sebesar 21,26\%. Sedangkan kadar abu tertinggi terdapat pada briket dengan perbandingan komposisi sekam padi dan ampsa tebu (3:2) gram sebesar dengan nilai sebesar 26,56\%. Kadar abu yang dihasilkan belum sesuai dengan standar mutu briket yaitu maksimal $8 \%$. Kadar abu merupakan salah satu parameter yang penting dalam menentukan kualitas briket karena bahan bakar tanpa abu memiliki sifat pembakaran yang lebih baik. Kadar abu dapat menyebabkan turunnya mutu briket karena dapat menurunkan nilai kalor. Penggunaan perekat dapat meningkatkan kadar abu karena adanya penambahan abu dari perekat yang digunakan. Peningkatan kadar abu juga dapat diakibatkan oleh garam-garam mineral yang tebentuk selama proses pengarangan. 


\subsection{Pengaruh Variasi Komposisi Bahan Baku terhadap Kadar Zat Terbang}

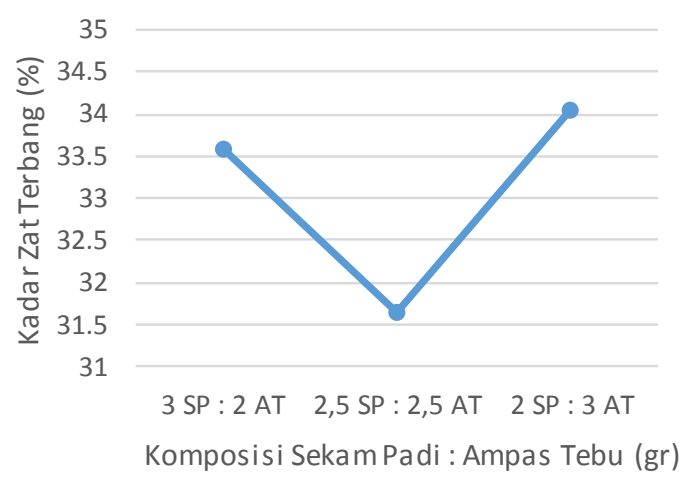

\section{Gambar 3. Grafik pengaruh variasi komposisi bahan baku terhadap kadar zat terbang}

Dari grafik di atas dapat diketahui bahwa nilai kadar zat terbang paling rendah yaitu briket dengan perbandingan komposisi sekam padi dan ampas tebu $(2,5: 2,5)$ gram sebesar $31,66 \%$. Sedangkan kadar zat terbang tertinggi terdapat pada briket dengan perbandingan komposisi sekam padi dan ampas tebu (2:3) gram sebesar dengan nilai sebesar $34,06 \%$.

Semakin tinggi jumlah kadar zat terbang maka akan menimbulkan jumlah asap yang semakin tinggi pada saat briket dinyalakan. Timbulnya asap yang tinggi dikarenakan adanya reaksi antara karbon monoksida (CO) dengan turunan alkohol. Kandungan karbon monoksida yang tinggi berdampak tidak baik bagi kesehatan dan lingkungan. Kadar zat terbang juga dipengaruhi oleh proses pengeringan briket. Semakin lama waktu pengeringan briket maka kadar air semakin menurun dan mengakibatkan kadar zat terbang juga menurun. Kadar zat terbang yang rendah menyebabkan semakin cepat asap menghilang dan mutu briket semakin meningkat.

\subsection{Pengaruh Variasi Komposisi Bahan Baku terhadap Kadar karbon}

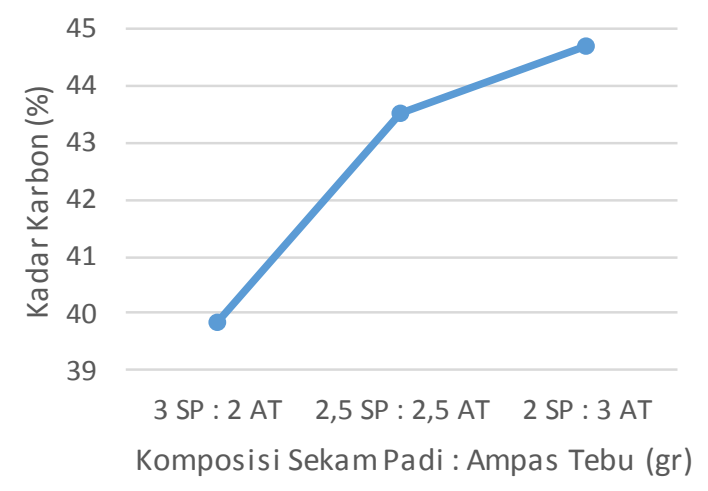

Gambar 4. Grafik pengaruh variasi komposisi bahan baku terhadap kadar karbon

Dari grafik di atas dapat diketahui bahwa nilai kadar karbon paling rendah yaitu briket dengan perbandingan komposisi sekam padi dan ampas tebu (3:2) gram sebesar 39,84\%. Sedangkan kadar karbon tertinggi terdapat pada briket dengan perbandingan komposisi sekam padi dan ampas tebu (2:3) gram sebesar dengan nilai sebesar 44,69\%. Kadar karbon yang dihasilkan belum sesuai dengan standar mutu. Kadar karbon dipengaruhi oleh kandungan kadar zat terbang dan kadar abu pada briket tersebut, semakin rendah nilai kadar abu maka nilai kadar karbon semakin tinggi. Semakin tinggi kadar karbon akan menghasilkan nilai kalor yang semakin tinggi begitupula sebaliknya. Kadar karbon juga dipengaruhi oleh kandungan air pada briket campuran sekam padi dan ampas tebu yang dihasilkan dan juga kurangnya lama penjemuran bahan baku .

\subsection{Pengaruh Variasi Komposisi Bahan Baku terhadap Nilai Kalor}

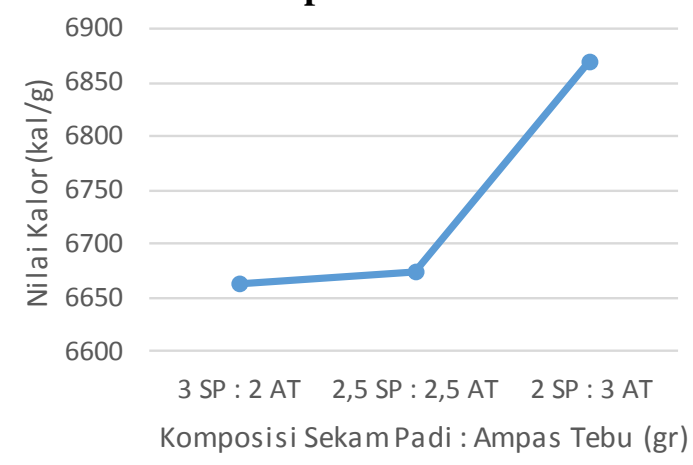

Gambar 5. Grafik pengaruh variasi komposisi bahan baku terhadap nilai kalor 
Berdasarkan hasil pengujian, nilai kalor yang dihasilkan pada briket dengan perbandingan komposisi sekam padi dan ampas tebu (3:2) sebesar 6663,002 $\mathrm{kal} / \mathrm{gram}$, pada briket dengan perbandingan komposisi sekam padi dan ampas tebu $(2,5: 2,5)$ nilai kalor yang dihasilkan sebesar 6674,879 $\mathrm{kal} / \mathrm{gram}$, sedangkan pada briket dengan perbandingan komposisi sekam padi dan ampas tebu (2:3) nilai kalor yang dihasilkan sebesar 6869,846 $\mathrm{kal} / \mathrm{gram}$.

Nilai kalor merupakan salah satu sifat penting untuk menentukan kualitas briket. Komposisi bahan bahan baku sangat berpengaruh terhadap nilai kalor. Dapat dilihat dengan komposisi ampas tebu yang semakin banyak nilai kalor semakin meningkat. Penambahan perekat juga menyebabkan nilai kalor briket semakin berkurang karena bahan perekat memiliki sifat termoplastik, yang artinya sukar terbakar dan membawa lebih banyak air dalam briket. Nilai kalor juga dipengaruhi oleh proses pengeringan bahan. Semakin lama waktu pengeringan akan menurunkan kadar air dan mengakibatkan nilai kalor. Hasil pengujian menunjukkan nilai kalor sudah memenuhi standar mutu yaitu minimal $5000 \mathrm{kal} / \mathrm{gram}$. Semakin besar nilai kalor, kualitas briket akan semakin baik.

\subsection{Pengaruh Proses Pengaragan terhadap Kualitas Briket}

Semakin tinggi suhu pengarangan maka semakin meningkat proses dehidrasi dalam briket yang menyebabkan air didalam briket semakin banyak yang menguap dan kadar airnya akan menurun. Semakin tinggi suhu pengarangan maka kadar zat terbang dalam briket semakin rendah sehingga kadar karbon semakin meningkat.. Akan tetapi kadar zat terbang yang rendah akan berakibat kepada nilai kalor yang rendah pula.

Suhu yang terlalu tinggi juga dapat menyebabkan kadar abu yang semakin menigkat. Meningkatnya kadar abu disebabkan oleh suhu pengarangan tinggi dan waktu pengarangan yang lama sehingga karbon akan habis terbakar dan menyisakan abu hasil pembakaran.

\section{KESIMPULAN}

Berdasarkan hasil penelitian yang dilakukan dapat disimpulkan bahwa variasi kompisisi bahan baku berpengaruh terhadap kualitas briket yang dihasilkan. Pada penelitian yang telah dilakukan beberapa parameter sudah sesuai dengan standar mutu briket yaitu kadar air dan nilai kalor. Briket yang memiliki kualitas terbaik menggunakan perbandingan komposisi 3 gram ampas tebu: 2 gram sekam padi dengan kdara air 8,30\%, kadar abu 21,26\%, kadar zat terbang $34,06 \%$, kadar karbon $44,69 \%$ dan nilai kalor sebesr $6869,846 \%$. Suhu pengarangan juga mempengaruhi kualitas briket yang dihasilkan.

\section{DAFTAR PUSTAKA}

Akenpuun, T. et al. (2020) 'Physical and Combustible Properties of Briquettes Produced from a Combination of Groundnut Shell, Rice Husk, Sawdust and Wastepaper using Starch as a Binder', Journal of Applied Sciences and Environmental Management, 24(1), pp. 171-177.

doi: doi.org/10.4314/jasem.v24i1.25.

Edwart, J. (2013). Laporan Briket Arang Kelapa. Geologi Pertambangan.

Mangalla, L. K. et al. (2019) 'Biobriket Karbonisasi Dari Cangkang Mete Dan Sekam Padi Untuk Energi Berkelanjutan', Jurnal Ilmiah Teknik Mesin, 10(2), pp. 1-6. doi: 10.5281/zenodo.3032856.

Manisi, L. et al. (2019) 'Pengaruh Variasi Komposisi Terhadap Karakteristik Briket Campuran Sekam Padi Dan Kulit Jambu Mete', Jurnal Ilmiah Mahasiswa Teknik Mesin, 4(2), pp. 60-67. Available at: http://ojs.uho.ac.id/index.php/ENTHALP Y.

Miskah, S. et al. (2016) 'Pengaruh Variasi Jumlah Campuran Perekat Tapioka Dan Semen Terhadap Pembuatan Biobriket Ampas Tebu', Jurnal Teknik Kimia, 22(4), pp. 11-18.

Oladeji, J. T. (2015) 'Theoretical Aspects of Biomass Briquetting: A Review Study', Journal of Energy Technologies and Policy, 5(3), pp. 72-81.

Rumiyanti, L. et al. (2018) 'Analisis Proksimat Pada Briket Arang Limbah Pertanian', Jurnal Fisika, 3(1), pp. 15-22.doi: doi.org/10.21009/SPEKTRA.031.03. 
Setiawan, B. and Syahrizal, I. (2018) 'Unjuk Kerja Campuran Briket Arang Ampas Tebu Dan Tempurung Kelapa', Jurnal Teknik Mesin Univ. Muhammadiyah Metro, 7(1), pp. 57-64. Available at: http://ojs.ummetro.ac.id/index.php/turbo.

Suryaningsih, S. and Nurhilal, O. (2018) 'Sustainable energy development of bio briquettes based on rice husk blended materials: an alternative energy source', Journal of Physics: Conference Series. doi: 10.1088/1742-6596/1013/1/012184.

Suryaningsih, S. et al. (2018) 'Fabrication and characterization of rice husk charcoal bio briquettes', in AIP Conference proceedings, pp. 1-6. doi: 10.1063/1.5021237. 